\title{
Short-Term Recruitment of Trees in a Forest Fragment in Singapore
}

\author{
Ayesha C. ERCELAWN Division of Biology, National Institute of Education, Nanyang Technological \\ University, Singapore \\ James V. LAFrANKIE Center for Tropical Forest Science, National Institute of Education, Nanyang \\ Technological University, Singapore
}

Shawn K. Y. LUM, LEE Sing Kong Division of Biology, National Institute of Education, Nanyang Technological University, Singapore

\begin{abstract}
To assess the current population dynamics of trees in an isolated 100-ha tropical forest fragment in Singapore we censused all trees $>=1 \mathrm{~cm}$ dbh in a 2-ha permanent plot in 1993 and again in $1995(\mathrm{~N}=13,470)$. We then examined the pattern of recruitment into the $1 \mathrm{~cm}$ dbh size class, comparing recruits to the existing flora and comparing recruitment rates among species to test hypotheses about patterns of short-term change. The overall plot recruitment rate was $6.5 \%$ (annualized rate of $2.6 \%$ ), comparable to recruitment rates found in tropical forests elsewhere in the world. The hypothesis that species diversity is declining was found to be untrue, the recruitment class had a slightly elevated diversity compared to the existing $1-3 \mathrm{~cm}$ dbh class. When we classified species by abundance class, floral form, dispersal form, stature class and successional status, we found no evidence that abundant species are becoming more abundant, nor was regeneration of dioecious species repressed, and all stature classes were replacing themselves at similar per-capita recruitment rates. There was no sign of successful invasion by secondary forest species and the majority of secondary forest species in the canopy show no evidence of replacing themselves. The only evidence of biologically significant change among recruits was in regard of dispersal syndromes. We found that species with abiotically dispersal (both Dipterocarpaceae and non-Dipterocarpaceae) showed per-capita recruitment rates of over $10 \%$, compared to $6.5 \%$ for biotically dispersed species. However, comparative data from large forests suggest that these high rates may be generally characteristic of these species. In contrast, the family Myristicaceae, rich in species and individuals, and closely associated with dispersers now extinct in Singapore, showed a recruitment rate of only $2.5 \%$, far below what comparative data from unfragmented forests portray as characteristic. Thus, in contrast to the bird and mammal populations, for which over half the species have been lost in the last 150 years, our data on the current short-term dynamics of trees reject the hypothesis that most species of Bukit Timah are in the midst of rapid decline.
\end{abstract}

Key words: fragment / Singapore / tropical rain forest / recruitment / regeneration / population dynamics / hill dipterocarp forest.

What is the conservation value of isolated fragments of species-rich tropical rain forests? As managed ecosystems, what can be done to accentuate their strengths and minimize their weaknesses? These questions have become increasingly common as relentless deforestation has transformed previously contiguous tropical forest into a patchwork landscape. Observational studies throughout the world have been uniform in showing that isolated fragments contain significantly fewer species of birds and mammals than are found in nearby forest with large areas (reviewed in Lovejoy et al., 1983, 1986; Saunders et al., 1991; Bierregaard et al., 1992; Turner \& Corlett, 1996). However, there have been 
few direct observations on the patterns of species loss over time, and most conclusions are based on inferences drawn from comparison of fragmented and contiguous forests. One of the few examples of actual time-series data comes from Singapore, a near-equatorial island adjacent to the Malay Peninsula, where the reduction of primary forest cover by $99.8 \%$ over 150 years has coincided with a loss of $28 \%$ of the total avifauna and nearly $50 \%$ of the resident forest avifauna (Corlett, 1988; Lim, 1992; Kang \& Hails, 1995). Trees appear to be more resistant to species loss. One recent rough estimate for Singapore is that about $20 \%$ of the pre-1850 tree flora has been lost (Turner et al., 1994), although higher rates are found in very small residual patches. For example, in a completely isolated 4-ha patch of original rain forest in the Singapore Botanical Gardens, Turner et al. (1996) compared the extensive historical series of herbarium specimens and a modern survey to estimate that nearly 50 $\%$ of the local 4-ha forest flora had disappeared over the last 100 years. But we have no clear data on the temporal patterns by which the species loss occurs, nor any indication of current trends.

The dynamics of tree populations are difficult to interpret from one-time surveys. In particular, the persistence of a species is not necessarily indicative of a sustainable population, in that an obligate pollinator or disperser could be missing. Thus, trees are in special need of direct observations on dynamics that focus on recruitment of juveniles. However, such studies are encumbered by the very large sample sizes need to accommodate the very high diversity that is the most interesting community feature of tropical forests trees.

One way to approach direct studies of forest tree dynamics is to make a series of large-scale census of all the trees entering into the smallest diameter class of a forest fragment. This provides a direct temporal view and avoids the pitfalls of interpreting static census data. If the forest community is undergoing any kind of compositional change, then that change should be evident in the patterns of recruitment of individual constituent species. Using this approach, we censused the new recruits in a mapped 2-ha plot in Singapore over 2 years, and compared the totals with the existing forest. Ideally, we would like to compare a temporal series of recruits and analyze changes in recruitment patterns. However, as a first step, we can evaluate the dynamic data of recruits by comparing the per-capita recruitment of individual species, and provide the first direct observations on short-term tree dynamics in a forest fragment. We use the results to test six hypotheses about the direction and rate of compositional change.

First, we test the hypothesis that species diversity is declining. This idea is rooted in the related ideas of island biogeographic theory (MacArthur \& Wilson, 1967) and the species-area relationship (Connor \& McCoy, 1976), where composition is determined by the balance between species immigration and extinction a balance that favors larger numbers in islands of greater size and proximity to a source of fresh immigrants. The idea of equilibrium amidst dynamic change can be seen in the 40-yr data sets from small permanent plots in Sungei Menyala, Malaysia (Wyatt-Smith, 1947, 1966; Manokaran \& Swaine, 1994). Here, trees over $10 \mathrm{~cm}$ dbh totaled 248 species in 1947 and nearly the same, 246 species, in 1985 despite a $20 \%$ turnover of species. The loss of 54 species was balanced by the immigration of 52 new species. Without a source of new immigrants, the diversity of this plot would have fallen by $20 \%$ in 40 years.

The remaining five hypotheses concern compositional changes in the forest. If fragmentation leads to fewer species, will these be a random set of the total forest flora, or will they be dominated by trees of certain physiological, morphological, or life-history characteristics? We examine this issue by classifying the constituent forest species, and comparing recruitment rates by class. The categories for classification that we use are: abundance, stature at maturity, floral form, dispersal form, and ruderal 
vs. primary forest species.

With regard to abundance, we simply ask, are common species becoming more common? Although the comparative dynamics of rare vs. common species has had a central role in community ecological theory, (e.g., Janzen, 1970) there are surprisingly few direct comparative observations. Connell et al. (1984) found that canopy species showed no compensatory trends based on abundance. However, for trees of smaller stature, they found that abundant species had lower recruitment rates than rare species. Studies of severely stressed environments such as logged-over forests indicate that a few species tend to dominate the succession (e.g., Uhl et al., 1988) and even under much lower levels of stress, shifts in abundance have been reported (Condit et al., 1992; Leigh et al., 1993; Turner et al., 1996). In the forest at Barro Colorado Island, Panama, drought was associated with an increase in abundance of the already abundant species (Condit et al., 1992). Small isolated islands in Panama have a higher dominance value than mainland ridge tops, and in some cases a single species represents as much as $60 \%$ of all trees (Leigh et al., 1993).

The third hypothesis concerns recruitment rates relative to stature. Stature at maturity for trees in our census varies from 2-35 m tall, and correlates with a wide variety of ecological attributes. Stature has been a focal point for some of the discussion concerning the fate of fragmented forests. For instance, Turner et al. (1996) suggested that in a 4-ha fragment in Singapore, small understory plants were being lost at a higher rate than were canopy trees. Similarly, Condit et al. (1995) found different patterns in mortality due to drought for understory treelets versus large trees in BCI, Panama.

The fourth hypothesis concerns recruitment rate relative to floral form. Dioecious species may be slightly more vulnerable to reduced habitat area than species with bisexual flowers. For dioecious species to reproduce, not only must there be another individual of the species in the vicinity but it must also be of the opposite sex, the probability of which is one-half or less if there is a gender bias (Bawa, 1985). Thus the effective density of dioecious species is necessarily lower than that of a species with bisexual flowers. It was from this perspective that Hubbell and Foster (1986) pointed out that in the 50-ha forest plot on Baro Colorado Island, Panama, there are very few species that are both rare and dioecious.

The fifth hypothesis concerns recruitment relative to dispersal syndrome. Most large birds and mammals have been lost from Singapore (Chin et al., 1995) and with them the potential for dispersal of large fruits. This loss may be reflected in the recruitment success of these species. In contrast, trees that are dispersed abiotically, by wind, water or ballistically, should respond to fragmentation more favorably than biotically dispersed species.

The sixth and final hypothesis tests the relative recruitment rates of species of the primary forest canopy vs. secondary forest species and ruderals. Fragmentation of a forest may increase opportunities for the invasion of secondary species as extensive edges are created, radiation levels increase, and external seed sources from secondary species increase.

\section{STUDY SITE}

The study was conducted at Bukit Timah Nature Reserve, Singapore (103 $\left.46^{\prime} \mathrm{E}, 1^{\circ} 21^{\prime} \mathrm{N}\right)$. This reserve encompasses approximately 100 ha of forest on the slopes of Bukit Timah hill (163 m a.s.1.) of which about two-thirds is unlogged forest. It lies within the center of the island of Singapore, only 8 $\mathrm{km}$ from the city center. The reserve has received some sort of protection since the mid 1800 s and was gazetted a Nature Reserve by 1939 (Corlett, 1988). 
The native flora and fauna of Singapore are characteristic of the Sunda Shelf in general, and of the Malay Peninsula in particular (Corlett, 1988, 1992, 1995a). The vegetation of Bukit Timah is best classified as a coastal hill dipterocarp forest. This type falls within the broad category of lowland mixed Dipterocarp forest, but with a composition distinguished by groves of seraya, Shorea cutisii (Symington, 1943; Wong, 1987). The body of the hill is composed of granite. The soils of Bukit Timah are classified as ultisols of the Rengam series and are derived from acidic granites, relatively poor in total $\mathrm{P}$ and total $\mathrm{N}(0.04 \mathrm{mg} / \mathrm{g}$ and $0.9 \mathrm{mg} / \mathrm{g}$ respectively) (Grubb et al., 1994). Singapore has an equatorial ever-wet climate with mean monthly temperatures of $25.5-27.3^{\circ} \mathrm{C}$ and a mean annual rainfall of $2579 \mathrm{~mm}$. Though fairly wet throughout the year, there is a slight seasonality with cooler, wetter months in November and December and dry, brighter months in February/March (Corlett, 1992).

The landscape bordering the north, south and west of the Nature Reserve is heavily urbanized, whereas to the east lies the 2000 ha Central Catchment Reserve. This Reserve includes scattered patches of primary forest within a matrix of mostly secondary forest. Bukit Timah and the Central Catchment have been separated by a multi-laned expressway since 1985 . More than half the bird species have disappeared from Bukit Timah (Lim, 1992; Kang \& Hails, 1995; Corlett, 1995b) and similarly high extinctions are reported for amphibians, reptiles, and mammals (Chin et al., 1995).

\section{METHODS}

The 2-ha permanent plot was level surveyed into 20-m square quadrants in April of 1995, using a clinometer and tripod mounted surveyors' compass. The plot measured 200 by $100 \mathrm{~m}$. We made two complete enumerations of all trees greater than or equal to $1 \mathrm{~cm} \mathrm{dbh}$, wherein each tree was provided with an aluminum tag, measured, identified and mapped to the nearest $10 \mathrm{~cm}$. The dates for the two censuses were April-June 1993, and November-December 1995. The census methods followed the standardized methods of the Center for Tropical Forest Science as initially developed at Barro Colorado Island, Panama and Pasoh Forest Reserve, Peninsular Malaysia (Manokaran et al., 1990). Modifications for local conditions are described in detail in Ercelawn et al. (in press).

Abundant and distinctive trees were identified in the field. For difficult and uncommon species, a leaf specimen was collected, the specimens were sorted into morpho-species and identified using the herbarium of the Singapore Botanic Gardens. All species were documented by permanent voucher specimens currently stored in a special collection at The National Institute of Education, Singapore (BT series, numbers 001-725). Nomenclature follows Tree Flora of Malaya (Whitmore, 1972, 1973; $\mathrm{Ng}, 1978,1989)$ updated where appropriate. A list of all species, voucher specimens, notes on identification and nomenclature are found in Ercelawn et al. (in press) together with individual species' distribution maps and diameter distribution tables.

Species recruitment rates are based on 792 individuals with relatively secure determinations. All recruitment rates reported are the number of trees that have entered the $1 \mathrm{~cm}$ class in the plot in 1995 , divided by the population in 1993, and multiplied by 100 . Species were divided into classes of floral type, dispersal type, stature, and secondary vs. primary species, for comparative analysis. We classified the plot species into three flower habits - dioecious, monoecious, and bisexual flowers. The classification was based on morphology, and the bisexual class may include species that are functionally unisexual. We chose two broad dispersal syndromes, abiotic dispersal (primarily wind, and a few ballistically dispersed species) and biotic dispersal. For the abiotic class, we segregated the species for Dipterocarpaceae to examine effects independent of that numerically dominant family. 
Among the biotically dispersed species, we segregate the family Myristicaceae because they are abundant, rich in species, and are known to be closely associated with dispersal by hornbills and other large birds, now extinct in Singapore (P. Poonswad, pers. com.). We defined three stature classes based on the final height these species achieve: 'small' trees included shrubs and small, understory trees, $10 \mathrm{~m}$ in height; 'medium' trees included mid-canopy trees 10 to $30 \mathrm{~m}$ in height and 'large' trees included all canopy and emergent trees $>30 \mathrm{~m}$ in height. Information for floral syndrome, dispersal syndrome, stature classifications and successional status came from The Tree Flora of Malaya (Whitmore, 1972, 1973; Ng, 1978, 1989), and the personal experience of the authors.

\section{RESULTS}

The Bukit Timah plot inventory included 13470 stems in 1993 (basal area of $40.5 \mathrm{~m}^{2} / \mathrm{ha}$ ) and 13142 stems in 1995 (basal area of $40.4 \mathrm{~m}^{2} / \mathrm{ha}$ ). Recruits for 1995 totaled 885 stems representing a recruitment rate of $6.5 \%$ of the 1993 population, or an annualized rate of about $2.6 \%$.

The first hypothesis asked whether the recruits represent a lower diversity than the existing forest. We approached this in two ways. First we plotted the diversity of recruits in relation to the overall species- individual curve for Bukit Timah plot, together with data for other forest plots, so as to graphically view the relative position of the class (Fig. 1). Species-individual curves have been shown to be diameter-independent, and a more robust basis of comparison for large plot data sets than species-area curves (Condit et al., 1996) The recruits fell just above the Bukit Timah species-

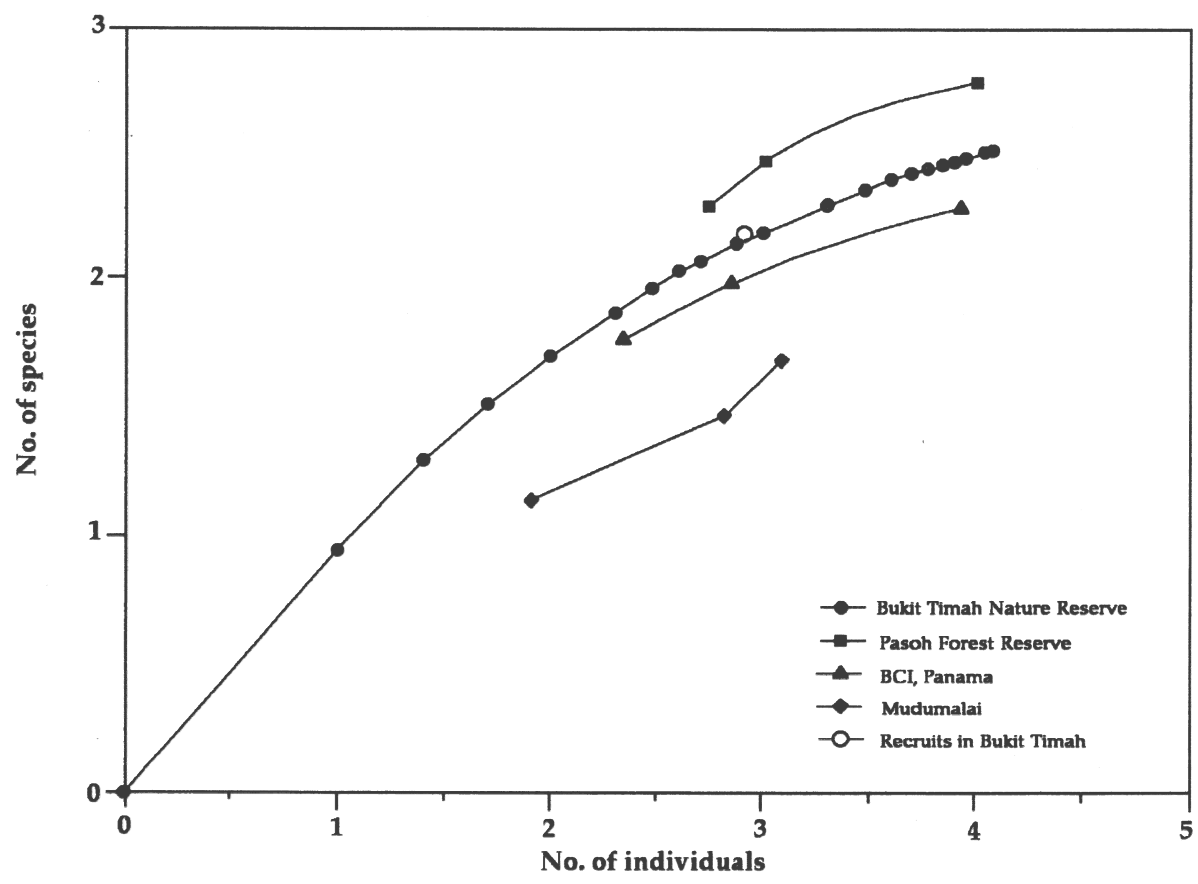

Fig. 1. Species diversity of recruits in a 2-ha permanent plot in Bukit Timah Nature Reserve, Singapore (single point) plotted against the log-log species-individual curve for the plot, and in comparison with species-individual curves for other tropical rain forests following Condit et al. 1996. 
Table 1 Recruitment rate 1993-1995 for a 2-ha permanent plot in Bukit Timah Nature Reserve Singapore, for 10 abundance classes, each of $32 \mathrm{spp}$, representing decreasing median abundance. Class I includes the most abundant species, Class 10 the least abundant.

\begin{tabular}{cccc}
\hline Class & Spp. & Median Abundance & Recruitment rate(\%) \\
\hline 1 & 32 & 162 & 6.1 \\
2 & 32 & 57 & 5.2 \\
3 & 32 & 30 & 6.2 \\
4 & 32 & 15 & 9.4 \\
5 & 32 & 9 & 10.1 \\
6 & 32 & 5 & 13.6 \\
7 & 32 & 3 & 17.8 \\
8 & 32 & 2 & 6.0 \\
9 & 32 & 1 & 8.6 \\
10 & 32 & 1 & 13.3 \\
\hline
\end{tabular}

Table 2 Recruitment rate 1993-1995 for a 2-ha permanent plot in Bukit Timah Nature Reserve Singapore, for species divided among three floral syndromes.

\begin{tabular}{lccccc}
\hline Flower & $\begin{array}{l}\text { No. of } \\
\text { individuals } \\
\text { in } 1993\end{array}$ & $\begin{array}{l}\text { Percent } \\
\text { of total } \\
\text { stems (\%) }\end{array}$ & $\begin{array}{l}\text { No. of } \\
\text { recruits in } \\
1995\end{array}$ & $\begin{array}{l}\text { Percent } \\
\text { of } \\
\text { recruits (\%) }\end{array}$ & $\begin{array}{l}\text { Percapita } \\
\text { recruitment } \\
\text { rate (\%) }\end{array}$ \\
\hline Dioecious & 4462 & 37 & 256 & 33 & 5.7 \\
Monoecious & 2618 & 21 & 180 & 23 & 6.9 \\
Bisexual & 5038 & 42 & 348 & 44 & 6.9 \\
\hline
\end{tabular}

individual curve indicating a slightly higher level of diversity than the existing forest. As a second approach, we compared the recruit class to 30 samples of $\mathrm{N}=792$ trees selected randomly from the 9000 trees between 2 to $3 \mathrm{~cm}$ in the 1993 census. The 30 samples had a mean species number of 141.5 ( standard deviation $=5.8$ ). The recruit diversity of 156 species was above the upper $95 \%$ confidence limits of the mean. The hypothesis that 1995 recruits have a lower diversity than the existing population can be decisively rejected; in fact the diversity is somewhat higher.

The second hypothesis was to test whether or not the more abundant trees gained in abundance as reflected in a higher representation among the recruits. First we calculated a simple correlation of abundance and per capita recruitment following Connell et al. (1984), which proved to be slightly negative (-0.25) and non-significant. As a second approach, we ranked the 320 species represented in the plot in decreasing order of abundance, and created 10 classes of 32 species each. Thus, class I included 32 species represented by 80 to 900 individuals each, whereas class 10 included 32 species represented by only 1 individual each. Recruitment rates between 1993 and 1995 varied greatly among classes, from $6 \%$ for class I to $13 \%$ for class 10 (Table 1) reflecting the slightly negative correlation just mentioned. Examples from the most abundant class include the two most numerous species, Santiria apiculata (Burseraceae) and Streblus elongatus (Moraceae), which accounted for 7.2 $\%$ and $6.3 \%$ of all stems, and had recruitment rates of $6 \%$ and $5 \%$ respectively. Thus, the 2-year recruitment patterns show no evidence that the most abundant trees are becoming more abundant. To the contrary, there is a slight favoring of the rare species.

The third hypothesis tested whether different floral morphologies are under- or over- represented among recruits. The per capita recruitment rate did not differ among the three types, although different floral morphs were represented by different proportions in the forest (Table 2). For example, bisexual 
Table 3 Recruitment rate 1993-1995 for a 2-ha permanent plot in Bukit Timah Nature Reserve Singapore, for species divided between biotic and abiotic dispersal modes.

\begin{tabular}{lcccc}
\hline $\begin{array}{l}\text { Dispersal mode } \\
\text { / Group (species) }\end{array}$ & $\begin{array}{l}\text { No. of } \\
\text { individual } \\
\text { in 1993 }\end{array}$ & $\begin{array}{l}\text { No. of } \\
\text { recruits } \\
\text { in 1995 }\end{array}$ & $\begin{array}{l}\text { Percapita } \\
\text { recruitment } \\
\text { rate (\%) }\end{array}$ \\
\hline Abiotic & Dipterocarpaceae & 616 & 62 & 10.1 \\
& Non-Dipterocarpaceae & 590 & 62 & 10.5 \\
& Total Abiotic & $\mathbf{1 2 0 6}$ & $\mathbf{1 2 4}$ & $\mathbf{1 0 . 3}$ \\
Biotic Myristicaceae & 280 & 7 & 2.5 \\
Non-Myristicaceae & 10704 & 661 & 6.2 \\
$\quad$ Total Biotic & 10984 & 668 & 6.1 \\
\hline
\end{tabular}

Table 4 Recruitment rate 1993-1995 for a 2-ha permanent plot in Bukit Timah Nature Reserve Singapore, for species divided among three stature classes.

\begin{tabular}{lccccc}
\hline $\begin{array}{l}\text { Stature } \\
\text { class }\end{array}$ & $\begin{array}{l}\text { No. of } \\
\text { individuals } \\
\text { in } 1993\end{array}$ & $\begin{array}{c}\text { Percent of } \\
\text { total stems } \\
(\%)\end{array}$ & $\begin{array}{l}\text { No. of } \\
\text { recruits } \\
\text { in } 1995\end{array}$ & $\begin{array}{l}\text { Percent of } \\
\text { total } \\
\text { recruits }\end{array}$ & $\begin{array}{l}\text { Per capita } \\
\text { recruitment rate } \\
(\%)\end{array}$ \\
\hline Small & 1824 & 15 & 118 & $15 \%$ & $\mathbf{6 . 4 7}$ \\
Medium & 3662 & 31 & 264 & $34 \%$ & $\mathbf{7 . 2 1}$ \\
Large & 6487 & 54 & 387 & $50 \%$ & 5.97 \\
\hline
\end{tabular}

species represented $44 \%$ of all recruits, but this simply reflects the dominance of bisexual species in the plot (42\% of stems). We found no evidence that dioecy leads to a depressed recruitment rate.

The fourth hypothesis tested whether species depending on biotic dispersal showed any difference in recruitment rate from abiotically dispersed species. Biotically dispersed species showed recruitment rates similar to the plot rate $(6.1 \%)$ while abiotic species had the very high recruitment rate of $10.3 \%$ (Table 3). This difference between the recruitment rate of the two dispersal modes is still evident after taking out Dipterocarpaceae which numerically dominate the abiotically dispersed individuals. In contrast, the family Myristicaceae, whose fruit dispersal generally depends on now extinct species of strong-flying birds such as hornbills, reveals very low recruitment rates of less than $2.5 \%$.

The fifth hypothesis concerned the relative recruitment rates of species of different stature classes. We found that the greatest number of recruits, $50 \%$, came from the large trees, the canopy/emergent class (Table 4). Fewer recruits came from medium sized trees (34\%) and the least from small trees $(15 \%)$. However, these numbers closely reflect the existing population structure, the three classes occupying $54 \%, 31 \%$, and $15 \%$ of all stems respectively. On a per-capita basis, all stature classes were represented among recruits at rates that fell within $10 \%$ of the overall plot recruitment rate of $6.5 \%$.

Of the 11 secondary forest species considered, only 4 species had any recruits at all, and these were restricted to only 1 or 2 individuals each (Table 5). The overall recruitment rate of these species was $2.7 \%$ of the 1993 population, less than half the overall plot recruitment rate of $6.5 \%$. Thus, there was no evidence that the secondary forest or ruderal species were successfully invading the forest fragment.

\section{DISCUSSION}

The results of this study present a paradox among the current observations on forest fragments. A 
Table 5 Recruitment rate 1993-1995 for a 2-ha permanent plot in Bukit Timah Nature Reserve Singapore, for secondary forest species in the plot.

\begin{tabular}{lcc}
\hline Species & No. in 1993 & Recruits in 1995 \\
\hline Timonius wallichianus (Rubiaceae) & 101 & 0 \\
Pellacalyx saccardianus,(Rhizophoraceae) & 45 & 1 \\
Campnosperma auriculatum (Anacardiaceae) & 12 & 1 \\
Endospermum diadenum (Euphorbiaceae) & 6 & 0 \\
Adinandra dumosa (Theaceae) & 3 & 2 \\
Vitex gamosepala (Verbenaceae) & 5 & 0 \\
Dillenia reticulata (Dilleniaceae) & 1 & 0 \\
Macaranga hypoleuca (Euphorbiaceae) & 3 & 0 \\
Rhodamnia trinerva (Myrtaceae) & 4 & 0 \\
Dillenia excelsa (Dilleniaceae) & 1 & 0 \\
Macaranga conifera (Euphorbiaceae) & 2 & 1 \\
\hline \multicolumn{1}{c}{ Total } & 183 & 5 \\
\hline
\end{tabular}

century of collecting and biological inventory in Singapore has demonstrated unequivocally that the forested ecosystems of the island have collapsed in many respects. The bird, mammal and insect fauna have all been greatly altered (Corlett, 1988; Chin et al., 1995.) Furthermore, the quantitative aspects of the collapse have been in general accordance with predictions based on biogeographic theory. Yet, when we consider the trees of the 2-ha plot in Bukit Timah, the population structure (LaFrankie et al., 1996) and the population dynamics, as reported here, show no evidence of dramatic change. For nearly all of the hypotheses tested, we rejected the view that the forest tree population is undergoing rapid change in character. The new recruits, taken as a class represent a forest that is nearly identical to the existing forest with regard to relative abundances, stature at maturity, proportion of dioecy, and proportion of secondary forest species.

In the test of dispersal we found a difference in per capita recruitment between biotically dispersed and abiotically dispersed trees, but caution is need in interpreting this result because there is still so little background and comparative data on the population dynamics of tropical trees. For example, it is likely, that high recruitment rates are in fact very general among the species of Dipterocarpaceae, and are naturally balanced by high mortality among saplings. The only comparable data comes from the 50-ha plot in the much larger Pasoh Forest Reserve (10,000 ha), approximately $200 \mathrm{~km}$ north of Singapore where the 16 species of the genus Shorea (Dipterocarpaceae) showed a recruitment rate nearly double the overall forest rate during 1990-1995 (LaFrankie, unpublished data). In contrast, the very low recruitment rates among the Myristicaceae in Bukit Timah, $2.5 \%$, appear contrary to their behaviour at Pasoh, where recruitment rate for Myristicaceae over 5 years, was $8 \%$ vs. a plot total of about $11 \%$ (LaFrankie, unpublished data).

One problem in the details of interpretation is that we know very little about the general dynamics of species loss, and in particular, about the details of the temporal sequence. Are species lost through episodic catastrophes, with intervening periods of equilibreal regeneration, or are they lost through a slow attrition? For instance, the $50 \%$ species loss over 100 years, as suggested for the 4-ha fragment in Singapore by Turner et al. (1996) would require an annual rate of loss of only $0.69 \%$ or, over the course of 2 years, about 4 or 5 species out of 321. Even though we monitored over 10,000 trees for two years, these rates of change are so low as to challenge the resolving power of the permanent plot.

The alternative is that species are lost in cataclysmic episodes. In this view, the problem of trees in forest fragments is not that they are unable to maintain near-equilibreal numbers in good times, but 
that they are incapable of recovery after a fire, wind storms and drought. The overall numbers that we find in Bukit Timah today, a high total diversity with low rates of loss, would be consistent with either view.

If we accept that area reduction must eventually lead to species loss, then the main question today is whether species loss will occur episodically in short cataclysms, perhaps related to droughts, or will it take place through slow year-to-year attrition. The Bukit Timah plot demonstrates that trees within a forest fragment isolated for over 100 years maintain per capita regeneration rates that contradict predictions of rapid species loss. Thus, we would answer the rhetorical question of the introduction by concluding yes, for trees, isolated fragments of species-rich rain forest can have high conservation value, and while the erosion of species diversity may be inevitable, it occurs at a rate slow enough to allow active management and intervention.

ACKNOWLEDGEMENTS The plot inventories would not have been possible without the excellent field help of Ng Lee Fui, Ooi Kai Li, Mislia Supar, and Tan Chuan Lim from The National Institute of Education in 1995 and Rosilah bte. Abdullah in 1993. We thank Hara Busu and Rosli Alias for their help in the fieldwork in 1993 and Wang Luan Keng and J. Heinrich Jessen for their help in 1995. We would like to thank Haji Sidek bin Kiah and Ali bin Ibrahim for their assistance in identifying voucher specimens. The project was supported by the Center for Tropical Forest Science/Smithsonian Tropical Research Institute and The National Institute of Education/Nanyang Technological University. This project was undertaken with the permission of National Parks Board, Singapore and we thank the Director for his help and encouragement.

\section{REFERENCES}

Bawa, K. S., Perry, D. R. \& Beach, J. H. 1985. Reproductive biology of tropical lowland rain forest trees. 1. Sexual systems and incompatibility mechanisms. American Jour. Bot. 72 (3): 331-345.

Bierregaard, R. O., Lovejoy, T. E., Kapos, V., Dos Santos, A. A. \& Hutchings, R. W. 1992. The biological dynamics of tropical rainforest fragments. Bioscience 42 (11): 859-866.

Chin, S. C., Corlett, R. T., Wee, Y. C. \& Geh, S. Y. 1995. Rain forest in the city: Bukit Timah Nature Reserve, Singapore. Gard. Bull. Sing. Supplement no. 3, 168 pp.

Condit, R., Hubbell, S. P., \& Foster, R. B. 1992. Short-term dynamics of a neotropical forest. Bioscience 42 ( 11 ): 822-828.

$\longrightarrow,-1$ - 1995. Mortality rates of 205 neotropical tree and shrub species and the impact of a severe drought. Ecological Monographs 65 (4): 419-439.

,-- LaFrankie, J. V., Sukmar, R., Manokaran, N., Foster, R. B. \& Ashton, P. S. 1996. Species-area and species-individual relationships for tropical trees: a comparison of three 50-ha plots. Journal of Ecology 84: 549-562.

Connell, J. H., Tracey, J. G. \& Webb, L. J. 1984. Compensatory recruitment, growth, and mortality as factors maintaining rain forest tree diversity. Ecological Monographs 54 (2): 141-164.

Corlett, R. T. 1988. Bukit Timah: the history and significance of a small rain-forest reserve. Environmental Conservation 15 (1): 37-44.

- 1992. The Angiosperm flora of Singapore 1. Introduction. Gard. Bull. Sing. 44 (1): 3-21. 1995a. Flowering plants at Bukit Timah. Gard. Bull. Sing. Supplement No. 3. 
1995b. The future of Bukit Timah Nature Reserve. Gard. Bull. Sing. Supplement No. 3: 165168.

Connor E., F. \& McCoy, E. D. 1979. The statistics and biology of the species area relationship. American Naturalist 113: 791-833.

Ercelawn, A. C., Lee, S. K., Lum, S. K. Y. \& LaFrankie, J. V. The 2-ha forest dynamic plot at Bukit Timah Nature Reserve, Singapore: Methods, maps and stand diameter tables. Research in Tropical Forest Science No. 1, 128 pp. Smithsonian Tropical Research Institute, Balboa, Panama. (in press)

Grubb, P. J., Turner, I. M. \& Burslem, D. F. R. P. 1994. Mineral nutrient status of coastal hill dipterocarp forest and Adinandra belukar in Singapore: analysis of soil, leaves and litter. Journal of Tropical Ecology 10: 559-577.

Hubbell, S.P. \& Foster, R. B. 1986. Commonness and rarity in a neotropical forest: implications for tropical tree conservation. In: Soule, M. E., ed. Conservation Biology: the Science of Scarcity and Diversity, pp. 205-231. Sinauer Associates. Massachusetts.

Janzen, D. H. 1970. Herbivores and the number of tree species in tropical forests. American Naturalist 104: 501-528.

Kang, N. \& Hails, C.J. 1995. Bukit Timah Nature Reserve Singapore: Birds. Gard. Bull. Sing. Supplement No. 3, 121-145.

LaFrankie, J. V. 1996. The contribution of large-scale forest dynamic plots to theoretical community ecology. In: Turner,I. M., Diong, C. H., Lim, S. L., Ng, P. K. L., eds. Biodiversity and the Dynamics of Ecosystems. DIWPA Series Vol. 1: 63-79.

., Lee, S. K. \& Ercelawn, A. C. 1996. Tree population structure in a tropical forest fragment in Singapore. Asian Journal of Tropical Biology 2: 39-48..

Leigh, E. G., Wright, S. J., Herre, E. A. \& Putz, F. E. 1993. The decline of tree diversity on newly isolated tropical islands: a test of a null hypothesis and some implications. Evolutionary Ecology 7: 76-102.

Lim, K. S. 1992. Vanishing Birds of Singapore. The Nature Society. Singapore.

Lovejoy, T. E., Bierregaard, R. O., Rylands, A. B., Malcolm, J. R., Quintela, C. E., Harper, L. H., Brown, K. S., Powell, A. H., N. Powell, G. V., Schubart, H. O. R. \& Hays M. B. 1986. Edge and other effects of isolation on Amazon forest fragments. In: Soule, M. E., ed. Conservation Biology: the science of scarcity and diversity, pp.257-285. Sinauer Associates. Massachusetts.

— - Rankin,J. M. \& Schubart, H. O. R. 1983. Ecological dynamics of tropical forest fragments. In: Sutton, E. L., Whitmore, T. C. \& Chadwick, A. C., eds., Tropical Rain Forest: Ecology and Management, 377-384. Blackwell Scientific Publications. Oxford.

MacArthur, R. H. \& Wilson, E.O. 1967. The Theory of Island Biogeography. Princeton University Press, Princeton, N.J.

Manokaran, N. \& Swaine, M. D. 1994. Population dynamics of trees in dipterocarp forests of Peninsular Malaysia. Malayan Forest Records No. 40, 173 pp. Forest Research Institute Malaysia.

— LaFrankie, J. V., Kochummen, K. M., Quah, E. S., Klahn, J. E., Ashton, P. S., \& Hubbell, S. P. 1990. Methodology for the 50-ha plot at Pasoh Forest Reserve. Research Pamphlett No. 104. 69 pp. Forest Research Institute Malaysia.

Ng, F. S. P., ed. 1978. Tree Flora of Malaya vol. 3. Longman, London. , ed. 1989. Tree Flora of Malaya vol. 4. Longman, London.

Saunders, D. A., Hobbs, R. J. \& Margules, C. R. 1991. Biological consequences of ecosystem 
fragmentation: a review. Conservation Biology 5 (1): 18-32.

Symington, C. F. 1943. Foresters' Manual of Dipterocarps. Malayan Forest Records 16.

Turner, 1. M., Tan, H.T., Wee, Y. C., Ali bin Ibrahim, Chew, P.T., Corlett, R.T. 1994. A study of plant extinctions in Singapore: lessons for the conservation of tropical biodiversity. Conservation Biology 8: 705-712.

- Chua, K. S., Ong, J. S. Y., Soong, B. C. \& Tan H. T. W. 1996. A century of plant species loss from an isolated fragment of lowland tropical rain forest. Conservation Biology 10 (4): 1229-1244.

- \& Corlett, R. 1996. The conservation value of strall, isolated fragments of lowland tropical rain forest. Trends in Ecology and Evolution 11 (8): 330-333.

Uhl, C., Buschbacher, R. \& S. Serrao, E. A. 1988. Abandoned pastures in eastern Amazonia. 1. Patterns of succession. Journal of Ecology 76: 663-681.

Whitmore, T. C., ed. 1972. Tree Flora of Malaya vol. 1. Longman, London. , ed. 1973. Tree Flora of Malaya vol. 2. Longman, London.

Wong, Y. K. 1987. Ecology of the trees of Bukit Timah Nature Reserve. Gard. Bull. Sing. 40: 45-76. Wyatt-Smith, J. 1949. Note on the rain forests in Malaya. The Malayan Forester 12: 58-64.

- 1966. Ecological studies on Malayan forests. Research Pamphlet no. 101. Forest Research Institute Malaysia, Kepong .

Received April 14, 1997

Accepted August 10, 1998

\section{Ayesha C. Ercelawn, James V. LaFrankie, Shawn K. Y. Lum \& Lee Sing Kong シンガポールの孤立林における樹木の短期間の加入数}

シンガポールの Bukit Timah に残る孤立した100 ha の熱帯林内で樹木個体群動態の現状を評価するた めに, 1993 年と 1995 年に 2 ha の永久調査区で直径 $1 \mathrm{~cm}$ 以上の樹木 13,470 本について調べた。その データから, 直径 $1 \mathrm{~m}$ 以上のクラスへの新規加入個体について, 既存の植物相との比較と, 種間の加 入率の比較を行い, 短期間の変化に関する仮説を検定した。調査区全体での加入率は $6.5 \%$ (年間 2.6 \%）であったが，世界各地で報告されている加入率と類似した值である。新規加入個体の多様性は直 径 1-3 cm クラスの集団よりもわずかだが多様性が高く, 多様性が減少するという仮説は真実でない ことが見いだされた。種を優占度・性型・散布型・成木の属する階層で区分すると，優占種がさらに 優占するとか, 雌雄異株の種が抑制されるとか, 特定の階層種の個体数当たりの更新率が高い, とい ったことはなかった。二次林の種の侵入が成功する兆候はなく，林冠相にある二次林種の大部分が更 新する様子がなかった。新規加入による生物学的に重要な唯一の変化は, 散布型に関してみられた。 生物に依存しない散布様式をもつ種群（フタバガキ科と非フタバガキ科の両方）の新規加入率は 10 \%だが, 生物に依存する散布様式をもつ種群では $6.5 \%$ であった。しかし, 大きな森林で得られてい る同様なデータから考えると, この高い加入率はこれらの種に一般的な性質かもしれない。一方, 二 クズク科は, 種数も個体数も多いが, シンガポールでは絶滅した動物によって主に散布される種群で, 新規加入率は $2.5 \%$ しかな, 孤立化していない森林の值よりずっと低かった。結論としては, 最近 150 年間に半数以上の種が失われた鳥類と哺乳類の個体群とは対照的に, 樹木の短期間の動態を調心゙ た我々のデータは, Bukit Timah のほとんどの種が急速な減少傾向にあるという仮説を否定している。 